\title{
Indonesia's Climate-Related Disasters and Health Adaptation Policy in the Build-Up to COP26 and Beyond
}

\author{
Rina Suryani Oktari 1,*(D), Febi Dwirahmadi ${ }^{2}$, Connie Cai Ru Gan ${ }^{2} \mathbb{D}$, Kristin Darundiyah ${ }^{3}$, \\ Pratomo Cahyo Nugroho ${ }^{4}$, Arif Wibowo ${ }^{5}$ and Cordia Chu ${ }^{2}$
}

check for updates

Citation: Oktari, R.S.; Dwirahmadi, F.; Gan, C.C.R.; Darundiyah, K.; Nugroho, P.C.; Wibowo, A.; Chu, C Indonesia's Climate-Related Disasters and Health Adaptation Policy in the Build-Up to COP26 and Beyond. Sustainability 2022, 14, 1006. https://doi.org/10.3390/su14021006

Academic Editor: Ashraf Dewan

Received: 30 November 2021

Accepted: 12 January 2022

Published: 17 January 2022

Publisher's Note: MDPI stays neutral with regard to jurisdictional claims in published maps and institutional affiliations.

Copyright: (C) 2022 by the authors. Licensee MDPI, Basel, Switzerland. This article is an open access article distributed under the terms and conditions of the Creative Commons Attribution (CC BY) license (https:// creativecommons.org/licenses/by/ $4.0 /)$.
1 Tsunami Disaster Mitigation Research Center (TDMRC), Department of Family Medicine, Faculty of Medicine, Universitas Syiah Kuala, Banda Aceh 23111, Indonesia

2 Centre for Environment and Population Health, School of Medicine and Dentistry, Griffith University, Brisbane, QLD 4222, Australia; f.dwirahmadi@griffith.edu.au (F.D.); c.gan@griffith.edu.au (C.C.R.G.); c.chu@griffith.edu.au (C.C.)

3 Indonesian Ministry of Health, Jakarta Selatan, Jakarta 12950, Indonesia; darundiyah@yahoo.com

4 Indonesian National Agency for Disaster Management, Jakarta Timur, Jakarta 13120, Indonesia; pratonugroho@gmail.com

5 Indonesian Ministry of Environment and Forestry, Jakarta Pusat, Jakarta 10270, Indonesia; arifwibowo2020@gmail.com

* Correspondence: okta@unsyiah.ac.id

\begin{abstract}
In recent years, Indonesia has experienced rapid increases in severe climate-related disasters have dramatically impacted populations unevenly; the poor and the vulnerable populations are most affected, and adaptive measures are urgently needed to protect and mitigate the impact on their health. However, very little is known about the existing measures addressing climate-related disasters and health impacts among vulnerable groups. WHO established a Health Emergency and Disaster Risk Management framework to urge governments and relevant actors to systematically collect evidence to develop science-based feasible adaptive strategies for priority groups. This study used scoping review methods to identify the action areas of Health-EDRM in policy documents in Indonesia, its content, and any potential gaps that require further study. The results from the documents' review were then reported and discussed at a national stakeholder consultation meeting. This study has identified several achievements, lessons learned, and challenges from strategies and policies for health adaptation in facing climate-related disasters in Indonesia. This study also proposed strategies and recommendations to support mobilizing and accelerating health adaptation actions towards climate-related disasters in Indonesia.
\end{abstract}

Keywords: disaster risk; climate change; public health; regulation; health-EDRM

\section{Introduction}

The Sendai Framework for Disaster Risk Reduction (SFDRR)2015-2030 aims to prevent new, and reduce existing, disaster risks, outlining targets and priority action plans for all member states. The framework drives significant progress in developing institutions and policies for mitigating disaster risks, it highlights "health" as both means and a goal. The health-focused measures are cited as a means to reduce disaster losses. Four out of the seven global targets are directly related to health [1]. To promote effective implementation of the SFDRR, the World Health Organization (WHO) published the Health Emergency and Disaster Risk Management (Health-EDRM) framework to set core principles and approaches that guide policy and practice of responses from international to local level [2]. It also recognizes that health should be centrally embedded in the current risk management institutions. The approaches are needed to align policies and actions to manage the steep rise in climate-related disaster events [3,4]. The presumption was (and is) that critical components including defined structures, roles, and responsibilities of governments and 
other actors present an opportunity to mitigate the increased disaster risks. There has been much discussion about disaster management policies to implement surveillance, early warning, and alert systems that enhance emergency preparedness for response across all hazards [5-7]. However, in Indonesia several studies showed that policies at the national level are not adequately responded to at the provincial and local levels [8-11].

Indonesia is highly vulnerable to extreme climatic events and disasters. According to the Indonesian Disaster Information Data (DIBI-BNPB), from 2005 to 2019, more than 78\% of disaster events were hydrometeorological disasters, including floods, extreme waves, land and forest fires, drought, and extreme weather [12]. Indonesia also ranks third among the world's most significant incidents of flood disasters from 1900 to 2020 [13]. The top ten list of countries or territories ranked by absolute death tolls is calculated from the disasters of the last 20 years, in Indonesia, with 41.6 total deaths per million inhabitants (278 events), ranked in the top two globally [13].

The severe health and socio-economic impacts of disaster events are being felt in the increased frequency and intensity of climate-induced disasters. Disasters happen when human lives are lost, and livelihoods are damaged or destroyed. Previous studies have shown that severe extreme disasters impact populations unevenly; the poor and the vulnerable populations are most affected and need adaptive measures and solutions to meet their needs [14-16]. However, very little is known about how the policies related to climate-related disasters and health impacts address health impacts among vulnerable groups. Thus, there is an urgent need to gather evidence to inform government and relevant sectors to develop targeted, adaptive strategies to address their needs.

As part of the United Nations Climate Change Conference in Glasgow (COP26) Health Program, more than 50 countries (including Indonesia) whose populations are highly impacted by climate change committed to develop climate responsive health system. This was declared in response to growing evidence of the impact of climate change on public health $[17,18]$.

This paper considers the evidence of practice and what is at stake in the quest for effective implementation and support of Health-EDRM activities. In the build-up to COP26 and beyond, this paper intends to examine climate emergency and disaster risk management policies through health lens in Indonesia. Specifically, this study aims to draw links between existing polies and health adaptation goals, identify gaps and outline the ways forward.

This paper is structured as follows: Following this introduction, Section 2 provides an overview of Indonesia's disaster governance, policy, and strategy. Section 3 explains the methods used in the study. Section 4 reports the finding summary of the scoping review of the policy documents and reports covering health adaptation towards climate-related disasters and analyses using the Health-EDRM framework. Section 4 also reflects the results from the scoping review and the national consultation. Section 5 concludes the practical and policy implications of the study, including some limitations and recommendations for future research.

\section{Disaster Management Governance, Policy and Strategy in Indonesia}

In Indonesia, disaster management was first regulated by Law no. 24 of 2007 concerning Disaster Management (DM). The DM Law was created to respond to the high threat of disasters in Indonesia, whether triggered by natural, non-natural, or man-made consequences. This DM Law is the basis for implementing disaster management in Indonesia. Regarding the impact of climate change, which triggers an increase in the hazard and vulnerability of disasters, it has not yet become the primary consideration or explicitly stated [19].

One of the laws explicitly or implicitly related to climate change and disaster risk reduction is Law no. 32 of 2009 concerning Environmental Protection and Management (Perlindungan dan Pengelolaan Lingkungan Hidup/PPLH). In general, the PPLH Law does not explicitly contain or provide terminology regarding disaster risk reduction. However, 
it mentions the obligations of the national and local governments to conduct a Strategic Environmental Assessment (Kajian Lingkungan Hidup Strategis/KLHS) before compiling the Regional Spatial Planning (Rencana Tata Ruang Wilayah/RTRW). KLHS itself functions as a formulation and evaluation of policies, plans, or programs that have the potential to cause environmental impacts and/or risks [20].

Besides, the Indonesian government has also issued a law that states the importance of providing health services in disaster conditions, namely Law no. 36 of 2009 concerning Health. In general, the concept of this Law pays more attention to responding after a disaster and does not focused on pre-disasters. The types of disasters referred to are still quite broad, thus presents opportunity to priorities climate-driven disasters [21].

In the context of the vulnerable population, Law no. 1 of 2014 concerning the Management of Coastal Areas and Small Islands also emphasizes the condition of coastal areas and islands that are extremely vulnerable, which are observing environment degradation caused by irresponsible human activities. It did acknowledged the influence of climate change driving the speed of sea level rise and exacerbates the vulnerability and risk of communities, coastal ecosystems, and small islands. However, this Law does not explicitly mention measures addressing the cascading effects of climate change [22]. Disaster risk reduction efforts are mostly reactive and only carried out through disaster responses through area rescue activities from the threat of storms and floods (which are types of climate-related disasters).

The increasing frequency of disasters that affects all sectors requires rapid and effective coordination that involve multiple stakeholders. Eight national clusters (see Figure 1) were formed according to the Decree of the Head of BNPB No. 173 of 2015 concerning National Clusters for Disaster Management [23].

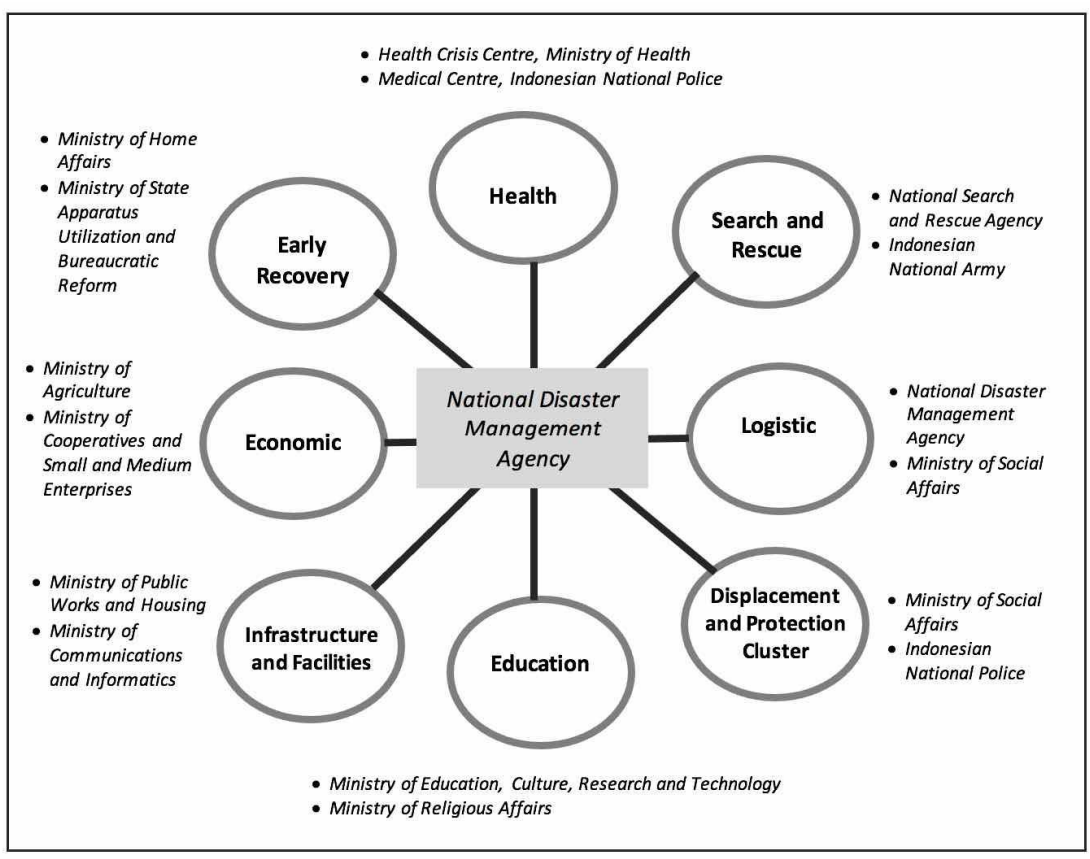

Figure 1. National Clusters for Disaster Management in Indonesia. Source: Adapted from [21].

There have been several regulations and guidelines issued by related ministries/agencies related to climate-related disasters and health adaptation at the operational level. These regulations and guidelines will be further discussed in this paper.

\section{Method}

In general, this study is divided into two stages: (i) Desktop review, and (ii) National stakeholder consultation meeting. 


\subsection{Desktop Review on Climate-Related Disaster Policy Addressing Health Impacts}

This study used a scoping study to identify the action areas of Health-EDRM in policy documents, its content, and any potential gaps that require further study. The research question was: What are the policies addressing the health impacts of vulnerable populations experiencing climate-related disasters? The search strategy of this review was systematic in its approach, employing established guidelines to inform the methodological process.

\subsubsection{Search Strategy and Document Selection}

Relevant official government websites were assessed to locate grey literature, including the National Disaster Management Authority (bnpb.go.id), the Ministry of Environment and Forestry (menlhk.go.id), the Ministry of National Development Planning (bappenas.go.id), the Ministry of Health (kemkes.go.id), Health Crisis Centre (pusatkrisis.kemkes.go.id), and the Ministry of Social Affairs (kemsos.go.id). The search for grey literature was also carried out on several websites of non-governmental organizations such as USAID-APIK Program (apikindonesia.or.id), MDMC (mdmc.or.id), and PMI-Indonesian Red Cross (pmi.or.id).

The used search terms including: "dokumen hukum", "undang-undang", "kebijakan", "rencana", "arahan", “keputusan", “perubahan iklim", “bencana”, "krisis kesehatan", “kesehatan", "kerentanan","mitigasi", "adaptasi", "implementasi", "monitoring", "integrasi", "konvergensi", “API dan PRB", "IKU”, "indikator kinerja utama", "pemantauan”, "keberlanjutan", "nasional", "Indonesia".

All identified policies and documents were listed in an Excel workbook and screened against agreed inclusion and exclusion criteria (see Table 1), first by title and executive summary or abstract and then in full text.

Table 1. Inclusion and Exclusion Criteria.

- Documents only focus on disasters and adaptations of other sectors, such as agriculture and rural development, construction, environment and natural resources, without any implication on Health.

- Type of document: Policy documents in Indonesia (Law regulations, circulars and directives)

- $\quad$ Language of document: Indonesian

- Documents were published on websites of relevant ministries, governmental organizations, departments or reputable organizations.

- Content of documents on disasters, climate change, health impacts, vulnerability and health adaptation strategies and policies to cope with climate-related disasters in Indonesia.

- $\quad$ They were published between the year 2010 to 2021 .
- Documents with non-climate related disasters such as earthquakes and tsunami; and not relating to climate change impacts;

- Considers with a focus more on GHG emission (mitigation); climate-related disaster;

- Documents were not directly related to Health (e.g., only flood modelling);

- No access to full paper/insecure link to access.
- Vulnerability studies/measurement were not related to

(Source: Author).

We searched and identified as many relevant policy documents as possible based on the selection criteria and source. The relevance and applicability of each policy document to the countries were assessed and categorized using the WHO Health Emergency and Disaster Risk Management (Health-EDRM). Policies addressing disasters not listed as climaterelated disasters such as earthquakes and tsunamis were excluded. This review does not cover policies that intervene in indirect health impacts such as urban heat, agriculture, and plants.

\subsubsection{Data Extraction}

The data extraction tool was developed in Excel for extracting information from identified documents. Two types of information in the documents were extracted: (1) information on documents' characteristics such as proposed institution, year of publication, type 
of document, objectives, and other details, (2) information based-on study objectives such as climate-related disaster, health impacts, vulnerable groups, measures/guidelines/planning/ policy/laws, execution levels, amendments over time, funding, and implementation gap.

\subsection{Stakeholder Consultation}

The consultation meeting aims to (i) present a preliminary summary of the state of evidence related to the impacts of climate-related disasters and health adaptation in Indonesia; and (ii) facilitate knowledge exchange of insights for establishing a common consensus to implement health adaptation plans for the vulnerable population in Indonesia.

This meeting is a means to report scoping review findings and obtain feedback from the participants. This meeting also aims to adopt a country-driven process to ensure ownership by the countries, cross-sectoral cooperation and coordination to strengthen and develop adaptation efforts.

There is no doubt that climate change and its associated impacts present a significant challenge to the world today and, unfortunately, will increasingly do so in the future. The immense challenges ahead make working together between sectors, countries, and regions more critical than ever. To this end, this meeting aims to provide a network platform to facilitate multi-sector and multi-disciplinary research partnerships and international cooperation.

More than 40 participants from professionals and decision-makers to government, industries, and non-government organizations attended this meeting. The inclusion criteria for the selection of meeting participants includes (i) experts or those who represent the key ministries or practitioners in the field of health, disaster, or climate change; (ii) have a working area or residence of Banda Aceh, Mataram, and Ambon City to represent Indonesia's western, central and eastern regions. All three cities have similar characteristics as coastal areas vulnerable to climate-related disasters. The participants were engaged in a dialogue to shape the future research agendas, policies, and collaboration strategies to deal with priority issues concerning climate change, disaster, vulnerable population, adaptive measures.

Moreover, to gain more in-depth information, six follow-up discussions have been carried out with several respected ministries, including the National Disaster Management Agency, the Ministry of Health, and the Ministry of Environment and Forestry.

\subsection{Data Analysis}

We employed qualitative content analysis to code text by identifying categories and themes. The policy documents were analyzed according to predefined themes based on WHO Health-EDRM Framework: (1) Policies, Strategies and Legislation; (2) Planning and Coordination; (3) Human Resources; (4) Financial Resources; (5) Information and Knowledge Management; (6) Risk Communication; (7) Health Infrastructure and Logistics; (8) Health and related Services; (9) Community capacities for Health EDRM; (10) Monitoring and Evaluation.

Data analysis was carried out by coding, classifying, and categorizing to formulate progress and challenges related to health adaptation policies and strategies towards climaterelated disasters in Indonesia. The triangulation method was used to confirm the data's trustworthiness and to check or compare the data collected from desktop reviews, consultations, and follow-up discussions. Based on the findings of this study, we then suggested several ways forward to support mobilizing and accelerating health adaptation actions.

\section{Results and Discussions}

\subsection{Overview of Reviewed Documents}

A total of 212 potential policies and documents were retrieved. After screening for relevance and significance, there were 38 regulations and 16 reports, guidelines, planning policies, and documents included in the analysis. The majority of policies in Indonesia that correlate to climate-related disasters and their impact on the health sector are issued by the 
National Disaster Management Agency and The Indonesian Ministry of Environment and Forestry (each published eight regulations), and The Indonesian Ministry of Health (seven regulations).

In Indonesia, health adaptation strategies to address climate-related disasters require the involvement of various key agencies including the Ministry of Environment and Forestry (Kementerian Lingkungan Hidup dan Kehutanan/KLHK), Ministry of Health (Kementerian Kesehatan/KEMENKES), and National Agency for Disaster Management (Badan Nasional Penanggulangan Bencana/BNPB). Each sector contributes according to its areas of jurisdiction and priorities which can be clearly reflected in key policy documents. While KLHK expresses challenges addressing the vulnerabilities from the environmental perspective, KEMENKES focuses on reducing susceptibility and enhancing the adaptive capacity of the individuals and societies, and BNPB oversees general disaster risk management governance and community resilience building.

Based on Law No 32/2009, KLHK holds the mandate to be the leading agency for climate change-related issues [18]. Following the Presidential Regulation, No. 16/2015 concerning the Ministry of Environment and Forestry, the National Agency for Climate Change (Dewan Nasional Perubahan Iklim/DNPI) was dismantled. KLHK then established a directorate that deals explicitly with climate change, namely the Directorate of Climate Change Control [24].

As health adaptation measures are perceived as an integral part of climate change impacts' management efforts; the directorate managed to launch policies related to health adaptation, for instance, the Ministry of Environment and Forestry Regulation No: P.33/ Menlhk/Setjen/Kum.1/3/2016 concerning the guideline to develop climate change adaptation plans. In this regulation, health is listed as one of six priority areas for adaptation measures in Indonesia (the other five priority areas are: food security, sustainable energy, shelter, infrastructure, and coastal and small islands' region) [25].

Aside from this policy, KLHK also released the Ministry of Environment and Forestry Regulation No: P.84/Menlhk/Setjen/Kum.1/11/2016 concerning the climate-resilient village program. In this program, there are four main components: (1) flood, drought, and landslides' prevention, (2) enhancing food security, (3) coastal flood and erosion management, and (4) climate-sensitive diseases prevention [26].

As for KEMENKES, health adaptation is framed as activities that aim to address the adverse health impacts of climate change, as referred in the Ministry of Health Regulation No: 1018/2011. Further, this regulation also describes that health adaptation measures can be in the form of (1) information dissemination and advocacy; (2) vulnerability mapping; (3) improvement of health system response; (4) legislation; (5) improvement of health service coverage; (6) improvement of human health resources; (7) improvement of climatesensitive disease control and prevention; (8) partnership; (9) community empowerment within the local health adaptation; and (10) improvement of disease surveillance and information systems [27].

Following the launch of Presidential Instruction no 1/2017 concerning the national healthy living community movement (Gerakan Masyarakat Hidup Sehat/GERMAS), KEMENKES produced policy document No 8/2019 on community empowerment in the health sector. This policy document highlights the importance of empowering community members in all health-sector-related activities, including disaster preparedness and health-crisis response. This policy also describes what is required to implement effective community empowerment in health promotion and preventive measures [28]. The Indonesian Health Minister, along with the other WHO South-East Asian Regional Office member states' health ministers, participated in the Malé Declaration that endorses implementing the WHO SEARO Framework for Action on Building Health Systems Resilience to Climate Change [29].

In the case of BNPB, while there is no particular policy document published by this agency that focuses solely on health adaptation, this agency sets and regulates the essential components related to disaster risk governance. The agency also contributes 
to health adaptation measures through facilitating community participation (Head of National Agency for Disaster Management or Peraturan Kepala/Perka BNPB No 11/2014); disabled population protection and participation (Perka BNPB No 14/2014); accountability (Perka BNPB No 10/2014); gender mainstreaming in disaster management (Perka BNPB No 13/2014); roles of private institutions in disaster management (Perka BNPB No 12/2014); logistic management in an emergency (Perka BNPB No 10/2012); disaster management command control (Perka BNPB No 10/2008); and needs assessment in the aftermath of disaster (Perka BNPB 15/2011) [30-36].

To facilitate the collaborative efforts between all stakeholders, the Indonesian President has launched Presidential Regulation No 87/2020 on the Indonesian Grand plan for Disaster Management 2022-2044. This policy document covers the plan of actions such as (1) hazard assessments; (2) understanding vulnerabilities; (3) disaster risk analysis; (4) disaster risk reduction measures; (5) disaster preparedness and response mechanisms; (6) task allocations, responsibilities and resource management. This grand plan serves as a guideline for provincial and district levels to develop their disaster management at a local level. Moreover, this grand plan features the convergence of disaster risk reduction, sustainable development and climate change adaptation measures [37].

\subsection{Analyzing Using WHO Health-EDRM Framework}

Human health has been acknowledged as one of the most critical aspects of climate change impacts since the earliest report of the Intergovernmental Panel on Climate Change (IPCC) in the early 90s. The World Health Organization (WHO) published its first assessment report on climate change and human health in 1996. This report presents the various possible impacts of climate change and stratospheric ozone depletion on population health [38]. Since then, many researchers and practitioners have worked collaboratively to design workable frameworks that aim to reduce the adverse impacts of climate change on population health [39-42].

The International Disasters Database (EM-DAT) defined disaster as an event that must meet at least one of the following criteria: ten or more people reported killed; 100 or more people reported affected; declaration of a state of emergency; call for international assistance, to be recorded as a disaster [40]. According to the UN Office for Disaster Risk Reduction (UNDRR), climate-related disasters were categorized as meteorological (storm, extreme temperature, fog), climatological (drought, glacial lake outburst, wildfire), or hydrological (flood, landslide, wave action) [43,44].

Reducing the impact caused by disasters is one of the most urgent priorities. WHO has developed the Health Emergency and Disaster Risk Management Framework (HealthEDRM), which is a substantial response to the increasing challenges of disasters. This framework emphasizes the importance of prevention, preparedness, and response and recovery to save lives and protect health. In its application, this framework outlines the need to work together-because Health-EDRM cannot be performed by one sector alone [45-47].

The health-EDRM framework incorporates a set of functions and elements that are represented from multisectoral emergency and disaster management, capacities for achieving the International Health Regulations/IHR [48], health system building blocks, and good practices from regions, countries, and communities. The framework focuses mainly on the health sector, noting the need for collaboration with many other sectors that make substantial contributions to reducing health risks and consequences [49-51].

In the context of Indonesia, several policies related to climate-related disasters and health adaptation are identified and mapped using the WHO H-EDRM framework (see Figure 2). Through this analysis, we can see how different policies from multiple stakeholders are interlinked. 


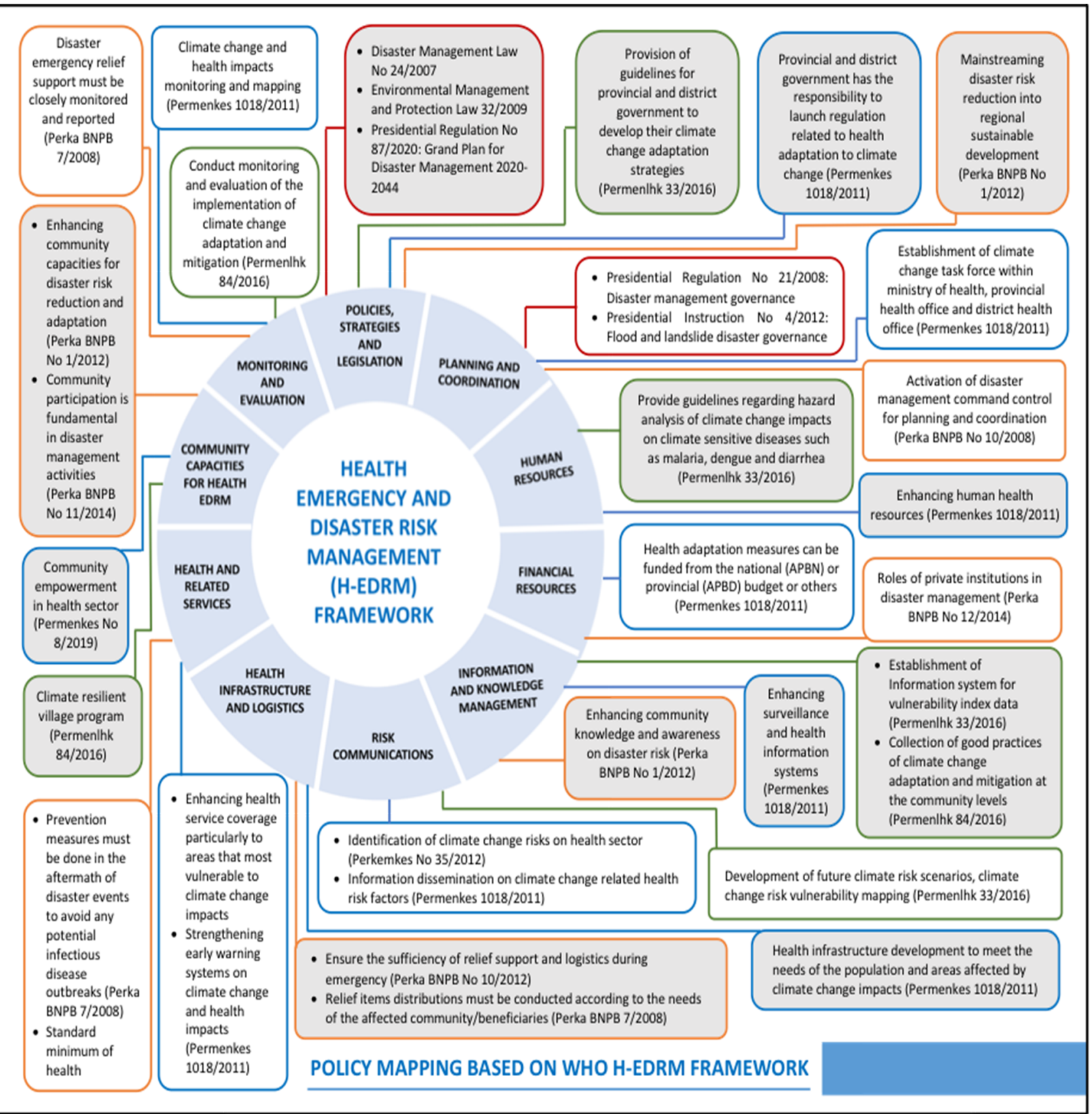

Figure 2. Mapping Climate-related Disaster and Health Adaptation Policies using WHO HealthEDRM Framework (Source: Authors). Notes: Policies issued by Law or presidential regulation (red line); regulation from KEMENKES (red line); BNPB (yellow line); KLHK (green line).

However, implementation in the field encountered several limitations or gaps or barriers. These challenges have been identified based on the results of the desktop review, consultation meeting and follow-up discussion as described in Table 2. 
Table 2. Findings summary.

\begin{tabular}{|c|c|c|c|}
\hline H-EDRM Component & Progress & Challenges & Ways Forward \\
\hline $\begin{array}{l}\text { Policies, Strategies and } \\
\text { Legislation }\end{array}$ & $\begin{array}{l}\text { - A number of regulations, } \\
\text { strategies and policies } \\
\text { have been published } \\
\text { [DR] } \\
\text { The Nationally } \\
\text { Determined } \\
\text { Contribution (NDC) } \\
\text { roadmap has mentioned } \\
\text { health issues (DR) }\end{array}$ & $\begin{array}{l}\text { Yet, health issues are not well } \\
\text { represented in non-health } \\
\text { sectors [DR] }\end{array}$ & $\begin{array}{l}\text { Advocacy efforts to ensure } \\
\text { that health takes a more } \\
\text { central position in } \\
\text { multisectoral legislations, } \\
\text { approaches, and actions }\end{array}$ \\
\hline Planning and Coordination & $\begin{array}{l}\text { Initiation of a joint secretariat, } \\
\text { monitoring dashboard and } \\
\text { Non-Government } \\
\text { Collaboration Forum [FD] }\end{array}$ & $\begin{array}{ll}\text { - } & \text { High sectoral ego [CM] } \\
\text { - } & \text { Coordination in crisis } \\
\text { management in the health } \\
\text { sector [FD] } \\
\text { - } \\
\text { Participation of other } \\
\text { sectors, both in sectors } \\
\text { with operations that } \\
\text { directly or indirectly affect } \\
\text { health issues [FD] }\end{array}$ & Inter-sectoral cooperation \\
\hline Human Resources & $\begin{array}{l}\text { Increasing the capacity of } \\
\text { human resources governed by } \\
\text { regulation by the Minister of } \\
\text { Health [DR] }\end{array}$ & $\begin{array}{ll}\text { - } & \text { Disaster command system } \\
\text { not functioning correctly } \\
\text { [DR] } \\
\text { - No policy related to } \\
\text { handling referrals of } \\
\text { patients [DR] } \\
\text { - Health worker capacity } \\
\text { still inadequate [DR] } \\
\text { - Health office does not yet } \\
\text { have a disaster } \\
\text { management team [DR] }\end{array}$ & $\begin{array}{ll}\text { - } & \text { Skilled and dedicated } \\
\text { human resources, both } \\
\text { national and local } \\
\text { - } \quad \text { Notable and long-term } \\
\text { investments in } \\
\text { education and training } \\
\text { in a systematic and } \\
\text { structured manner }\end{array}$ \\
\hline
\end{tabular}

- Health adaptation funded from the National or Regional Revenue and Expenditure Budget or other sources [DR]

Financial Resources

- Funds allocation in the health sector is mainly used for pre-disaster activities (75\%) [FD]
Disaster risk reduction has not been prioritized by many district/city governments [FD]
Allocate adequate funding by the government and other related institutions
Information and Knowledge Management
Several information systems have been developed [DR]
- How to document every process of the disaster management process [CM]

- Research-based evidence, knowledge, and practice and the development of innovative risk management techniques [CM]
Establishment of effective knowledge management mechanism 
Table 2. Cont.

\begin{tabular}{|c|c|c|c|}
\hline H-EDRM Component & Progress & Challenges & Ways Forward \\
\hline Risk Communications & $\begin{array}{l}\text { Identification of risks, } \\
\text { information dissemination } \\
\text { and development of future } \\
\text { risk scenarios and mapping } \\
\text { have been regulated [DR] }\end{array}$ & $\begin{array}{l}\text { Dissemination of conflicting } \\
\text { information }[\mathbf{C M}]\end{array}$ & 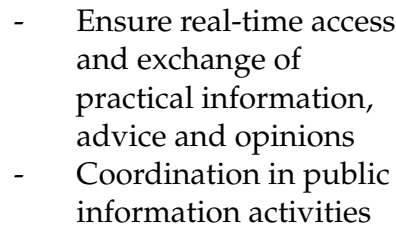 \\
\hline
\end{tabular}

Health Infrastructure and Logistics
Regulation exists to ensure the sufficiency of logistics and relief items distribution [DR]
- How to enable effective health response and recovery [FD]

- How to protect public and private investment [FD]
Ensure a safe and secure condition of health

infrastructure and logistics
- Increase service delivery

Lack of attention to vulnerable groups who require special attention/treatment, particularly for health-related needs [CM] to meet the growing health needs of catastrophe situations

- Take specific actions to address specific hazards

systems on climate change and health impacts [DR]
Various initiatives to build resilience at the village level

Community Capacities for Health EDRM

\section{(i.e., Disaster Resilient Village,}

Healthy Climate Village, Climate Village Program) [DR]

\section{How to build community} capacity [CM]
The need for synergy between programs carried out at the village level
Monitoring and evaluation with the existing authorities and mechanisms within the institution, both at national and local levels [DR]
No standard indicators to monitor program risk, capacity and implementation [FD]
Integration into existing health sector monitoring systems

Notes: [DR] = desktop review; [CM] = Consultation Meeting; [FD] = Follow-up Discussion.

\subsubsection{Policies, Strategies and Legislation}

In sum, the review show that a number of regulations, strategies and policies related to climate-related disasters and health adaptation have been published in Indonesia. However, health is not well represented in policies and strategies developed by non-health sectors. Advocacy efforts to assure a more central position for health in multisectoral legislations, approaches, and actions. There needs to be support and a concrete and intense collaboration design in implementing climate-related disasters and health adaptation policies. It is necessary to have a link between stakeholders and their respective roles and to become a national priority and how implementation can be carried out in specific locations and potential areas.

The development of the Nationally Determined Contribution (NDC) roadmap for adaptation aspects is the commitment of the Indonesian government in reducing vulnerability and risk, increasing adaptive capacity, and strengthening resilience. The NDC document's position is as an umbrella at the national and regional levels to strengthen the climate change adaptation strategies. Indonesia's updated NDC highlights progress beyond the previous NDC, notably increasing adaptation ambition as detailed in the programs, strategies, and activities to promote economic, social, and livelihood resilience, and ecological and landscape resilience [52]. The calculated indicators used in the NDC include health issues, potential losses to climate change, in line with the initiatives encouraged in the COP26 Health Program, namely strengthening the inclusion of health in their NDCs by quantifying the potential health co-benefits of national climate mitigation commitments [17]. 


\subsubsection{Planning and Coordination}

The high sectoral ego is one of the underlying reasons hindering smooth coordination. The strength of the sectoral ego can blunt coordination efforts and make coordination a meaningless routine activity [53]. Each sector will fight for its interests. Inter-sectoral cooperation can be established if the interests of work units are guaranteed.

Coordination in crisis management in the health sector is not only a purely technical activity involving the health authority, but it also necessitates the participation of other sectors, sectors with operations that directly or indirectly affect health issues. The national government has initiated a joint secretariat, monitoring dashboard and Non-Government Collaboration Forum for the National Disaster Management Plan and Master Plan for Disaster Management to coordinate various agencies' activities/ministers [54].

This joint secretariat consists of cross ministries and agencies under the coordination of the Steering Committee (SC) to ensure the mainstreaming of the National Disaster Management Plan. The Joint Secretariat uses a dashboard to show the progress and achievements of the National Disaster Management Plan. The dashboard also provides information related to the National Disaster Management Plan results and the cross-sectoral issues that develop in its implementation. The Non-Government Collaboration Forum solicits commitments and contributions from non-Governmental institutions in achieving the National Disaster Management Plan targets. In the Non-Government Collaboration Forum, tracking and tagging of the achievement of the National Disaster Management Plan targets are also carried out based on the Annual Report of the Non-Governmental Institutions/Institutions involved [54].

\subsubsection{Human Resources}

Increasing the capacity of human resources in the health sector is also one of the adaptation strategies of the health sector to the impacts of climate change in Indonesia, which is governed by regulation by the Minister of Health [27].

Skilled and dedicated human resources are needed as an adaptation strategy for the health sector, both national and local. Notable and long-term investments in education and training are required systematically and in a structured manner. Some of the skills and competencies that need to be trained include emergency planning, incident management, epidemiology, information management, risk and needs assessment, logistics, risk communication, and health service delivery $[2,55]$. However, human resource management also needs planning for staff needs (including capacity building for emergency response), occupational health and safety, and education and training for competency development.

As per this review's findings, some of the problems that often occur in the field related to human resources in the health sector include: the disaster command system is not functioning correctly, there is no policy related to handling referrals of patients affected by disasters, health worker capacity in disaster management is still inadequate, and the health office does not yet have a disaster management team [56].

\subsubsection{Financial Resources}

To develop capacity and implement programs and activities related to the adaptation of the health sector in the face of climate-related disasters, it is necessary to allocate adequate funding by the government, including the Ministry of Health and other related institutions. The regulation states that health adaptation measures can be funded from the National Revenue and Expenditure Budget (Anggaran Pendapatan dan Belanja Negara or APBN) or the Regional Revenue and Expenditure Budget (Anggaran Pendapatan dan Belanja Daerah or APBD) or other resources. The role of private institutions is also essential in financing the adaptation program for the health sector.

As stated by the expert from the Ministry of Health, the allocation of funds related to disasters in the health sector is used for pre-disaster activities (75\%), during a disaster, and post-disaster activities (25\%). There are numerous actions for pre-disaster activities, particularly for building human resource capacity, contingency planning, facility and 
infrastructure procurement, monitoring, and evaluation. At the regional level, funding for disaster management programs is also primarily contained in the relevant Regional Work Units (Satuan Kerja Perangkat Daerah or SKPD. The funding can be sourced from the APBD, APBN, and foreign aid. However, regional leaders' goodwill is critical because this health issue involves regional authority. Unfortunately, many district/city governments have not prioritized disaster risk reduction. When viewed from the existing disaster risk index, almost all regions in Indonesia are at risk of a disaster. In addition, the regional paradigm recognizes that disaster management is the responsibility of the Regional Disaster Management Agency (Badan Penanggulangan Bencana Daerah or BPBD). If the Regional Health Office allocates a disaster budget, it will be questioned.

\subsubsection{Information and Knowledge Management}

Information and knowledge management capabilities must be strengthened to enhance the health sector's adaptation to climate-related disasters. This effort is needed to support risk/needs' assessment, disease surveillance and other early warning systems, public communications, and other related strategies.

However, the challenge has been figuring out how to document every disaster management process so that adequate reference documentation is available in the future for disaster risk reduction. The collection, analysis, and dissemination of information must be harmonized across all relevant sectors. There needs to be a knowledge management mechanism implemented to ensure that "the right information reaches the right people at the right time". According to research, the significance of knowledge management practices has been demonstrated to improve the effectiveness and performance of disaster management activities [57]. The evolution of evidence, knowledge, and practice and the development of innovative risk management techniques are all needed to be supported by research. Evidence-based technical guidance is also required to enhance capacity through training programs and health system changes.

\subsubsection{Risk Communications}

Effective communication is needed in an adaptation strategy in the health sector, including risk communication, especially when dealing with other sectors, government authorities, media, and the public. It is necessary to ensure real-time access and exchange of information, advice and opinions so that everyone at risk can make informed decisions and take action to prevent, mitigate and respond to potential emergencies. Public information activities need to be coordinated among stakeholders to avoid disseminating conflicting information and adapted to the risks and needs of diverse at-risk populations, including those with higher levels of vulnerability [58-60].

The primary purpose of risk communication is to help people make informed decisions about avoiding or managing risk. In addition, risk communication helps plan based on facts and scientific data. Risk communication provides education and information, and suggests hazard prevention behavior [2].

\subsubsection{Health Infrastructure and Logistics}

Health facilities and critical public infrastructures must be ensured safe and secure. They must be prepared for emergencies and can protect the lives of their residents, enable an effective health response and recovery, protect public and private investment, support sustainability, and reduce the impact of health care on the climate and environment. Essential services in health facilities, such as water, sanitation, and energy, also need to be ensured that they are available and continue to function before, during, and after a disaster event. The provision of supporting logistics also needs to be prepared, including the initial placement of drugs and supplies, an effective supply chain, and a reliable transportation and telecommunications system. 


\subsubsection{Health and Related Services}

This review's findings demonstrate that policies to assure health and related services focus on increasing health service coverage, especially in areas most vulnerable to climate change impacts, and strengthening early warning systems on climate change and health impacts. In the aftermath of disasters, preventative measures must be taken to minimize infectious disease epidemics and adhere to minimum health standards.

However, the challenge of adapting health to disaster situations in Indonesia, according to the consultation meeting, is the lack of attention to vulnerable groups who require special attention/treatment, particularly for health-related needs. This challenge needs serious attention considering the rise in climate-related disasters in Indonesia, which have had adverse health consequences, and the urgent need for adaptation methods to lower the risks and vulnerabilities of the most vulnerable groups [61].

Public health facilities must be well prepared to respond effectively to a disaster that has an enormous impact on the health sector. Health facilities should be able to increase service delivery to meet the growing health needs of catastrophe situations (e.g., by increasing bed capacity, establishing temporary facilities or mobile clinics, and so on) as well as take specific actions to address specific hazards.

\subsubsection{Community Capacities for Health EDRM}

The community's active participation in the health adaptation strategy to climaterelated disasters is critical. Communities could participate in risk assessments to identify local hazards and vulnerabilities so that actions can be formulated to reduce risks before a disaster occurs. Communities could also play a significant role in emergency response, recovery and reconstruction efforts. Communities could contribute in conducting surveillance, building household preparedness, increasing capacity in providing first aid, and taking various actions at the site level before, during and after disasters.

Various initiatives to build resilience at the village level have been carried out. The National Disaster Management Agency (BNPB) initiated the Disaster Resilient Village (Desa Tangguh Bencana or Destana) program, which is a village that has the independent ability to adapt and deal with disaster threats and recover quickly from the adverse effects of disasters [62].

The Ministry of Health (KEMENKES) has initiated a Healthy Climate Village (Desa Sehat Iklim), abbreviated as DESA-DESI. This program aims to create healthy and independent communities adaptive to climate change. The development of activities in DESA-DESI needs to be coordinated and synergized with other programs and activities implemented to strengthen efforts to control climate change at the site level. Healthy Climate Village activities are focused on strengthening the adaptive capacity of the community in the health sector [63].

One of the strategies of the Ministry of Environment and Forestry (KLHK) to control climate change is to encourage multi-stakeholder cooperation to strengthen climate change adaptation and mitigation capacity at the community-based site level through the implementation of the Climate Village Program (Program Kampung Iklim or ProKlim). The various initiatives carried out by the various ministries are expected to synergize so that adaptation and mitigation activities can be more developed so that a climate-resilient society is formed, accompanied by an increase in the welfare of the local community [26].

\subsubsection{Monitoring and Evaluation}

In this study, we identify multiple institutions have engaged in monitoring and evaluating the implementation of the adaptation strategy towards climate-related disasters. Reports of achievements and benefits are also obtained through monitoring, evaluation, and reporting mechanisms. The analysis of policy documents shows that the monitoring and evaluation process is performed to ensure the progress of adaptation efforts and aspects of supporting program sustainability. It aims to monitor the implementation of adaptation programs and activities to follow the plans that have been prepared. 
Processes for monitoring progress toward achieving the health sector's core adaptation goals and capacities need to be integrated into existing health sector monitoring systems. This includes the need for standard indicators to monitor program risk, capacity and implementation. Ongoing monitoring can be complemented by periodic evaluations, particularly preparedness (e.g., simulations), response, and recovery activities.

\section{Conclusions}

This study has identified several gaps and challenges, which includes: (i) climaterelated disasters and/or human-induced climate change impacts have not been acknowledged in the current primary disaster management law, (ii) the interconnected nature of climate change impacts on health requires a set of interlinked stakeholders and policies, (iii) lack of a shared framework that engages multiple stakeholders for moderating climate change impacts on population health (e.g., most agencies involved in climate-related disasters are still fragmented), (iv) lack of coordination across related institutions), (v) lack of policies that focus on cross-boundary information and resource sharing, (vi) sectoral ego is also a persistent issue; every stakeholder has a desire to raise their flag, (vii) most policies are still at country/national level, translation to become actionable policies at local/provincial levels is still lacking.

Several recommendations have been formulated. First, advocacy efforts assuring that health takes a more central position in multisectoral legislations, approaches, and actions. Second, establish a shared/common framework that involves multiple stakeholders for health adaptation. Third is the need to translate national policies to the local context. Fourth, strengthen leadership and facilitation skills for effective collaborative governance of health adaptation at local levels.

This research is solely based on examining policy papers pertaining to the health sector's adaptation to climate-related disasters. This study does not detail how these policies are being implemented in the field. As a result, more research is needed to identify the factors contributing to the disparity between existing policies and their field execution.

This paper recognizes the need to develop and implement a system of public health care policies in the context of climate change, ensuring the rights of vulnerable social groups. It contributes to a burgeoning research area at the nexus of climate-related disasters and health adaptation policy. Our findings reaffirm the importance of climate-health adaptation. Finally, considering the co-creation of policies with relevant stakeholders as a key for climate action at the national and sub-national level is arguably a critical opportunity for addressing research gaps in our knowledge of the role of collaborative governance as a driver of effective climate adaptation.

Author Contributions: Conceptualization, R.S.O., F.D., C.C.R.G. and C.C.; methodology, R.S.O., F.D., C.C.R.G. and C.C.; validation, R.S.O. and F.D.; formal analysis, R.S.O., F.D., K.D., P.C.N. and A.W.; investigation, R.S.O. and F.D.; data curation, R.S.O. and F.D.; writing-original draft preparation, R.S.O. and F.D.; writing-review and editing, R.S.O., F.D., C.C.R.G., K.D., P.C.N., A.W. and C.C. All authors have read and agreed to the published version of the manuscript.

Funding: This research was funded by the Centre for Health Development-World Health Organization (WHO), Kobe: WKC-HEDRM-K19006 and the 2021 World Class Professors Program held by the Indonesian Ministry of Education and Culture.

Acknowledgments: The authors would like to acknowledge the support from Universitas Syiah Kuala, Griffith University, Indonesian Ministry of Health, Indonesian National Agency for Disaster Management and Indonesian Ministry of Environment and Forestry. The authors would also like to thank all stakeholder involved during the consultation meeting.

Conflicts of Interest: The authors declare no conflict of interest. The funding organization had no role in the design of the study; in the collection, analyses, or interpretation of data; in the writing of the manuscript, or in the decision to publish the results. 


\section{References}

1. Sendai Framework for Disaster Risk Reduction 2015-2030, United Nations International Strategy for Disaster Reduction (UNISDR). Available online: https:/ / www.undrr.org/publication/sendai-framework-disaster-risk-reduction-2015-2030 (accessed on 14 March 2021)

2. World Health Organization. Health Emergency and Disaster Risk Management Framework. 2019. Available online: https://www who.int/hac/techguidance/preparedness/health-emergency-and-disaster-risk-management-framework-eng.pdf (accessed on 14 March 2021).

3. Field, C.B.; Barros, V.; Stocker, T.F.; Dahe, Q. Managing the Risks of Extreme Events and Disasters to Advance Climate Change Adaptation: Special Report of the Intergovernmental Panel on Climate Change; Cambridge University Press: Cambridge, UK, 2012.

4. Annex, I. Managing the risks of extreme events and disasters to advance climate change adaptation. Sciences 2012, 10, 97-104.

5. Malilay, J.; Heumann, M.; Perrotta, D.; Wolkin, A.F.; Schnall, A.H.; Podgornik, M.N.; Simms, E.F. The role of applied epidemiology methods in the disaster management cycle. Am. J. Public Health 2014, 104, 2092-2102. [CrossRef] [PubMed]

6. Botchey, I.M.; Paruk, F.; Hung, Y.W.; Mehmood, A.; Bachani, A.; Hassan, S.; Hyder, A.A. Establishing mHealth Injury Surveillance Systems in Kenya. Prehospital Disaster Med. 2017, 32, S61. [CrossRef]

7. Karo, B.; Haskew, C.; Khan, A.S.; Polonsky, J.A.; Mazhar, M.K.A.; Buddha, N. World Health Organization early warning, alert and response system in the Rohingya crisis, Bangladesh, 2017-2018. Emerg. Infect. Dis. 2018, 24, 2074. [CrossRef] [PubMed]

8. Sumaryana, A.U.; Utami, S.B.; Pancasilawan, R. Creating Sustainable Disaster Management Collaboration in Indonesia. Int. J. Civ. Eng. Technol. 2019, 10, 2435-2440.

9. Fahlevi, H.; Indriani, M.; Oktari, R.S. Is the Indonesian disaster response budget correlated with disaster risk? Jàmbá: J. Disaster Risk Stud. 2019, 11, 1-9. [CrossRef] [PubMed]

10. Nurdin, N.; Rafliana, I.; Hidayati, S.; Oktari, R.S.; Djalante, R. Integrating Disaster Risk Reduction and Climate Change Adaptation into School Curricula: From National Policy to Local Implementation. In Disaster Risk Reduction in Indonesia; Djalante, R., Garschagen, M., Thomalla, F., Shaw, R., Eds.; Disaster Risk Reduction (Methods, Approaches and Practices); Springer: Cham, Switzerland, 2017; pp. 213-234.

11. Simarmata, H.A.; Suryandaru, R.W. Institutions and planning: A reflection from disaster management planning in Indonesia. In Global Sustainability; Werlen, B., Ed.; Springer: Cham, Switzerland, 2015; pp. 239-265.

12. Indonesian Disaster Information Data (DIBI-BNPB). Available online: https://www.dibi.bnpb.go.id (accessed on 14 March 2021).

13. Centre for Research on the Epidemiology of Disasters-CRED. Disaster Year in Review 2020: Global Trends and Perspectives; Cred Crunch; Université Catholique de Louvain: Brussels, Belgium, 2021; Volume 62, p. 2.

14. Keim, M.E. Climate-Related Disasters: The Role of Prevention for Managing Health Risk. In Global Climate Change and Human Health: From Science to Practice; Lemery, J., Knowlton, K., Sorensen, C., Eds.; John Wiley \& Sons: Hoboken, NJ, USA, 2021 ; p. 25.

15. Benevolenza, M.A.; DeRigne, L. The impact of climate change and natural disasters on vulnerable populations: A systematic review of literature. J. Hum. Behav. Soc. Environ. 2019, 29, 266-281. [CrossRef]

16. Banwell, N.; Rutherford, S.; Mackey, B.; Chu, C. Towards improved linkage of disaster risk reduction and climate change adaptation in health: A review. Int. J. Environ. Res. Public Health 2018, 15, 793. [CrossRef] [PubMed]

17. World Health Organization. COP26 Health Programme. 2021. Available online: https://www.who.int/initiatives/cop26-healthprogramme (accessed on 14 March 2021).

18. World Health Organization. Countries Commit to Develop Climate-Smart Health Care at COP26 UN Climate Conference. 2021. Available online: https:/ / www.who.int/news/item/09-11-2021-countries-commit-to-develop-climate-smart-health-care-atcop26-un-climate-conference (accessed on 14 March 2021).

19. Indonesian Law No. 24 of 2007 Concerning Disaster Management. Available online: https://www.ifrc.org/docs/IDRL/956EN. pdf (accessed on 14 March 2021).

20. Indonesian Law No. 32 of 2009 Concerning Environmental Protection and Management. Available online: https://www.fao.org/ faolex/results/details/en/c/LEX-FAOC097643/ (accessed on 14 March 2021).

21. Indonesian Law No. 36 of 2009 Concerning Health. Available online: https://www.ilo.org/dyn/natlex/natlex4.detail?p_lang= en\&p_isn=91185 (accessed on 14 March 2021).

22. Indonesian Law No. 1 of 2014 Concerning the Amendment to Law No. 27 of 2007 on Management of Coastal Areas and Small Islands. Available online: https:/ / peraturan.bpk.go.id/Home/Details/38521/uu-no-1-tahun-2014 (accessed on 14 March 2021).

23. Decree of the Head of BNPB No. 173 of 2014 Concerning National Clusters for Disaster Management. Available online: https:/ / bnpb.go.id/uploads/regulation/1085/Perka\%20No\%2014\%20Tahun\%202014.pdf (accessed on 14 March 2021).

24. Presidential Regulation, No. 16 of 2015 concerning the Ministry of Environment and Forestry. Available online: https: / peraturan. bpk.go.id/Home/Details/41738/perpres-no-16-tahun-2015 (accessed on 14 March 2021).

25. Ministry of Environment and Forestry Regulation No: P.33/Menlhk/Setjen/Kum.1/3/2016 Concerning the Guideline to Develop Climate Change Adaptation Plan. Available online: http://ditjenppi.menlhk.go.id/reddplus/images/resources/permen/ permen33.pdf (accessed on 14 March 2021).

26. Ministry of Environment and Forestry Regulation Number P.84/Menlhk/Setjen/Kum.1/11/2016 Concerning Climate-Resilient Village Program. Available online: http:/ /jdih.menlhk.co.id/uploads/files/P.84.pdf (accessed on 14 March 2021).

27. Ministry of Health Regulation No. 1018 of 2011 Concerning Health Sector Adaptation Strategy to the Climate Change Impact. Available online: https:/ / peraturan.go.id/common/dokumen/bn/2011/bn344-2011.pdf (accessed on 14 March 2021). 
28. Ministry of Health Regulation No. 8 of 2019 on Community Empowerment in Health Sector. Available online: https: / peraturan. bpk.go.id/Home/Details/111722/permenkes-no-8-tahun-2019 (accessed on 14 March 2021).

29. World Health Organization. Framework for Action in Building Health Systems Resilience to Climate Change in South-East Asia Region, 2017-2022; WHO: Geneva, Switzerland, 2017.

30. Head of National Agency for Disaster Management No. 11 of 2014 Concerning Community Participation in Disaster Management. Available online: https:/ / bnpb.go.id/berita/perka-bnpb-no-11-2014-tentang-peran-serta-masyarakat-dalam-penanggulanganbencana (accessed on 14 March 2021).

31. Head of National Agency for Disaster Management No. 14 of 2014 Concerning Handling, Protection and Participation of Persons with Disabilities in Disaster Management. Available online: https:/ /bnpb.go.id/berita/perka-bnpb-no-14-2014-tentangpenanganan-perlindungan-dan-partisipasi-penyandang-disabilitas-dalam-pb (accessed on 14 March 2021).

32. Head of National Agency for Disaster Management No. 10 of 2014 concerning Guidelines for Verification of Financial Accountability Documents within BNPB. Available online: https://bnpb.go.id/produk-hukum/peraturan-kepala-bnpb/peraturankepala-bnpb-no-10-tahun-2014 (accessed on 14 March 2021).

33. Head of National Agency for Disaster Management No. 13 of 2014 concerning Gender Mainstreaming in Disaster Management. Available online: https:/ / bnpb.go.id/berita/perka-bnpb-no-13-2014-tentang-pengarusutamaan-gender-di-bidang-pb (accessed on 14 March 2021).

34. Head of National Agency for Disaster Management No. 10 of 2012 Concerning Management of Logistics Assistance during Emergencies. Available online: https://bnpb.go.id/produk-hukum/peraturan-kepala-bnpb/peraturan-kepala-bnpb-no-10 -tahun-2012 (accessed on 14 March 2021).

35. Head of National Agency for Disaster Management No. 10 of 2008 Concerning Disaster Emergency Response Command. Available online: https:/ / www.bnpb.go.id/index.php/produk-hukum/peraturan-kepala-bnpb/peraturan-kepala-bnpb-no10-tahun-2008 (accessed on 14 March 2021).

36. Head of National Agency for Disaster Management No. 15 of 2011 Concerning Guidelines for Post-Disaster Needs Assessment. Available online: https:/ / www.bnpb.go.id/index.php/produk-hukum/peraturan-kepala-bnpb/peraturan-kepala-bnpb-no15-tahun-2011 (accessed on 14 March 2021).

37. Presidential Regulation No. 87 of 2020 on the Indonesian Grand Plan for Disaster Management 2022-2044. Available online: https: / peraturan.bpk.go.id/Home/Details/146481/perpres-no-87-tahun-2020 (accessed on 14 March 2021).

38. World Health Organization. Climate Change and Human Health: An Assessment (No. WHO/EHG/96.7). Available online: https:/ /apps.who.int/iris/handle/10665/62989 (accessed on 14 March 2021).

39. McMichael, A.J.; Kovats, R.S. Climate change and climate variability: Adaptations to reduce adverse health impacts. Environ. Monit. Assess. 2000, 61, 49-64. [CrossRef]

40. World Health Organization (WHO). Climate Change and Human Health: Impact and Adaptation. Available online: https: / /apps.who.int/iris/handle/10665/66776 (accessed on 14 March 2021).

41. Grambsch, A.; Menne, B. Adaptation and adaptive capacity in the public health context. In Climate Change and Health: Risks and Responses; McMichael, A.J., Campbell-Lendrum, D.H., Corvalan, C.F., Ebi, K.L., Githeko, A., Scheraga, J.D., Woodward, A., Eds.; World Health Organization: Geneva, Switzerland, 2003; pp. 220-236.

42. EM-DAT. The International Disaster Database. Centre for Research on the Epidemiology of Disaster (CRED). EM-DAT Glossary. Available online: https:/ / www.emdat.be/Glossary (accessed on 14 March 2021).

43. UN Office for Disaster Risk Reduction (UNDRR). Terminology. Available online: www.undrr.org/terminology (accessed on 14 March 2021).

44. Lo, S.T.T.; Chan, E.Y.Y.; Chan, G.K.W.; Murray, V.; Abrahams, J.; Ardalan, A.; Kayano, R.; Yau, J.C.W. Health emergency and disaster risk management (Health-EDRM): Developing the research field within the Sendai framework paradigm. Int. J. Disaster Risk Sci. 2017, 8, 145-149. [CrossRef]

45. Kayano, R.; Chan, E.Y.; Murray, V.; Abrahams, J.; Barber, S.L. WHO thematic platform for health emergency and disaster risk management research network (TPRN): Report of the Kobe expert meeting. Int. J. Environ. Res. Public Health 2019, 16, 1232. [CrossRef] [PubMed]

46. Kayano, R.; Nomura, S.; Abrahams, J.; Huda, Q.; Chan, E.Y.; Murray, V. Progress towards the development of research agenda and the launch of knowledge hub: The who thematic platform for health emergency and disaster risk management research network (health edrm rn). Int. J. Environ. Res. Public Health 2021, 18, 4959. [CrossRef] [PubMed]

47. Wright, N.; Fagan, L.; Lapitan, J.M.; Kayano, R.; Abrahams, J.; Huda, Q.; Murray, V. Health emergency and disaster risk management: Five years into implementation of the Sendai framework. Int. J. Disaster Risk Sci. 2020, 11, 206-217. [CrossRef]

48. World Health Organization. International Health Regulations. Available online: https://www.who.int/publications/i/item/97 89241580496 (accessed on 14 March 2021).

49. Hung, K.K.; Mashino, S.; Chan, E.Y.; MacDermot, M.K.; Balsari, S.; Ciottone, G.R.; Della Corte, F.; Dell'Aringa, M.F.; Egawa, S.; Evio, B.D.; et al. Health Workforce Development in Health Emergency and Disaster Risk Management: The Need for EvidenceBased Recommendations. Int. J. Environ. Res. Public Health 2021, 18, 3382. [CrossRef]

50. Nomura, S.; Kayano, R.; Egawa, S.; Harada, N.; Koido, Y. Expected Scopes of Health Emergency and Disaster Risk Management (Health EDRM): Report on the Expert Workshop at the Annual Conference for the Japanese Association for Disaster Medicine 2020. Int. J. Environ. Res. Public Health 2021, 18, 4447. [CrossRef] [PubMed] 
51. Chan, E.Y.; Sham, T.S.; Shahzada, T.S.; Dubois, C.; Huang, Z.; Liu, S.; Hung, K.K.; Tse, S.L.; Kwok, K.O.; Chung, P.H.; et al. Narrative Review on Health-EDRM Primary Prevention Measures for Vector-Borne Diseases. Int. J. Environ. Res. Public Health 2020, 17, 5981. [CrossRef] [PubMed]

52. Updated Nationally Determined Contribution Republic of Indonesia. Available online: https://www4.unfccc.int/sites/ ndcstaging/PublishedDocuments/Indonesia\%20First/Updated\%20NDC\%20Indonesia\%202021\%20-\%20corrected \%20version. pdf (accessed on 14 March 2021).

53. Dwirahmadi, F.; Rutherford, S.; Phung, D.; Chu, C. Understanding the operational concept of a flood-resilient urban community in Jakarta, Indonesia, from the perspectives of disaster risk reduction, climate change adaptation and development agencies. Int. J. Environ. Res. Public Health 2019, 16, 3993. [CrossRef] [PubMed]

54. National Disaster Management Plan 2020-2024. Available online: https://ss.bnpb.go.id/ss/pages/renas-2020 (accessed on 20 October 2021). (In Indonesian).

55. Rose, D.A.; Murthy, S.; Brooks, J.; Bryant, J. The evolution of public health emergency management as a field of practice. Am. J. Public Health 2017, 107, S126-S133. [CrossRef]

56. Review Book in Health Crisis Management Year 2017. Available online: https://www.who.int/docs/default-source/searo/ indonesia/non-who-publications / 2017-health-emergency-op-centre-information-product---disaster-review-bahasa.pdf? sfvrsn=7e5563ed_2 (accessed on 20 October 2021). (In Indonesian).

57. Oktari, R.S.; Munadi, K.; Idroes, R.; Sofyan, H. Knowledge management practices in disaster management: Systematic review. Int. J. Disaster Risk Reduct. 2020, 51, 101881. [CrossRef]

58. Zhong, M.; Xiao, L.; Zhang, Q.; Jiang, T. Risk Perception, Risk Communication, and Mitigation Actions of Flash Floods: Results from a Survey in Three Types of Communities. Sustainability 2021, 13, 12389. [CrossRef]

59. Adu-Gyamfi, B.; Shaw, R. Characterizing Risk Communication and Awareness for Sustainable Society: The Case of Foreign Residents in the Tokyo Metropolitan Area of Japan. Sustainability 2021, 13, 5786. [CrossRef]

60. Ministry of Health. Risk Communication Guideline for Health Crisis Management; Ministry of Health: Jakarta, Indonesia, 2021.

61. Gan, C.C.; Oktari, R.S.; Nguyen, H.X.; Yuan, L.; Yu, X.; Alisha, K.C.; Hanh, T.T.; Phung, D.T.; Dwirahmadi, F.; Liu, T.; et al. A scoping review of climate-related disasters in China, Indonesia and Vietnam: Disasters, health impacts, vulnerable populations and adaptation measures. Int. J. Disaster Risk Reduct. 2021, 66, 102608. [CrossRef]

62. Head of National Agency for Disaster Management No. 1/2012 Concerning General Guidelines for Disaster Resilient Villages. Available online: https:/ / bnpb.go.id/berita/perka-bnpb-no-1-2012-tentang-pedoman-umum-desa-kelurahan-tangguh-bencana (accessed on 14 March 2021).

63. Ministry of Health. Technical Guideline for Healthy Climate Village; Ministry of Health: Jakarta, Indonesia, 2021; Unpublished Work. 